\title{
The impact of widely spaced soil conservation trees on hill pastoral systems
}

\author{
A.J. WALL ${ }^{1}$, A.D. MACKAY ${ }^{2}$, P.D. KEMP ${ }^{1}$, A.G. GILLINGHAM ${ }^{2}$ and W.R.N. EDWARDS ${ }^{3}$ \\ ${ }^{1}$ Plant Science Department, Massey University, Palmerston North \\ ${ }^{2}$ AgResearch, Grasslands Research Centre, PB 11008, Palmerston North \\ ${ }^{3}$ HortResearch, Palmerston North
}

\begin{abstract}
An estimated 3.7 million ha or $33 \%$ of the North Island requires the application of significant soil conservation measures to be able to physically sustain pastoral enterprises. Traditionally, erosion control measures on hill farmland have centred on the planting of hardwood trees, such as poplars and willows, at wide spacings. Research and experience has confirmed that where hardwood trees are adequately planted and tended, they significantly reduce the magnitude of soil erosion and maintain soil stability. However, the effects that such erosion-control plantings have on pasture and animal production owing to changes in the farm microclimate, soil and water resources remains relatively unresearched in New Zealand.
\end{abstract}

Keywords: hardwood trees, physical sustainability, silvipastoral systems, soil conservation

\section{Background}

The development of North Island soft-rock hill terrain into pasture has increased the magnitude of hillside soil erosion 2- to 10-fold, even though the frequency of erosion events remains unaltered (Miller et al. 1996). This soil erosion reduces the productive capacities of pastoral hill farms (Blaschke et al. 1992). On-farm degradation can be seen as the physical removal of pasture by mass movement and fluvial erosion processes; depletion of fertile topsoil by accelerated gross or insidious soil loss; reduced soil water-holding capacity owing to shallower soils with poor physical structure and lower organic matter content; and damage to fixed structures such as farm tracks and fences (Clough \& Hicks 1993; Hicks et al. 1993; Blaschke et al. 1992; Lambert et al. 1984). Pasture production on erosion scars takes about 20 to 40 years to reach levels equivalent to 70 to $80 \%$ of neighbouring uneroded sites, with little further recovery thereafter (Lambert et al. 1984; Douglas et al. 1986; DeRose et al. 1995). This indicates that on hillsides where mass movement erosion is severe and/ or frequent, current production levels from pastoral regimes will increasingly become difficult to sustain
(Trustrum et al. 1984). Eyles \& Newsome (1992), using the New Zealand Land Resource Inventory database as well as other physical parameters, have estimated that 3.7 million ha or $33 \%$ of the North Island requires significant soil conservation measures in order to be able to physically sustain pastoral land uses.

The tree species most commonly used for the stabilisation of easier sloped $\left(<28^{\circ}\right)$ North Island pastoral hill land are space-planted poplars and willows, and Pinus radiata forestry (Thompson \& Luckman 1993). Where factors such as steep gradients, water stress, ongoing soil disturbance, and desiccating winds inhibit tree establishment and subsequent growth, alternative hardwood tree species, such as Eucalyptus and Acacia (wattles), are increasingly being planted (Van Kraayenoord \& Hathaway 1986). Such inhibitory factors are common to eastern North Island regions.

The planting patterns and tree spacings used for pastoral hillside stabilisation are not usually uniform over entire paddocks. High tree stockings are used where erosion is severe or active, and spacings are progressively widened as trees extend into more stable ground (Van Kraayenoord \& Hathaway 1986). The tree stockings used for soil conservation range between 25 to 150 stems/ha (Wilkinson 1995; Thompson \& Luckman 1993), and though understorey pasture is present at these stockings its effectiveness for animal production has been little researched except for agroforestry trials with Pinus radiata (Maclaren 1988) (Figure 1).

Figure 1 schematically shows the continuum from tree-pasture systems to forestry systems, and illustrates the tree stockings that have potential for livestock grazing.

The development of whole-farm packages for the integration and management of silvipastoral systems using widely spaced hardwood soil conservation trees, that can be applied to a wide range of environments, requires a thorough understanding of how such trees utilise available farm resources and in turn affect existing pastoral systems. Information presently available is fragmented and incomplete. For this reason MAFpol contracted a review of research and practical experience, to identify the potential advantages and disadvantages that hardwood soil conservation trees may incur when incorporated into pastoral hill systems. 
Figure 1 Schematic diagram showing the continuum from tree-pasture systems to forestry systems.

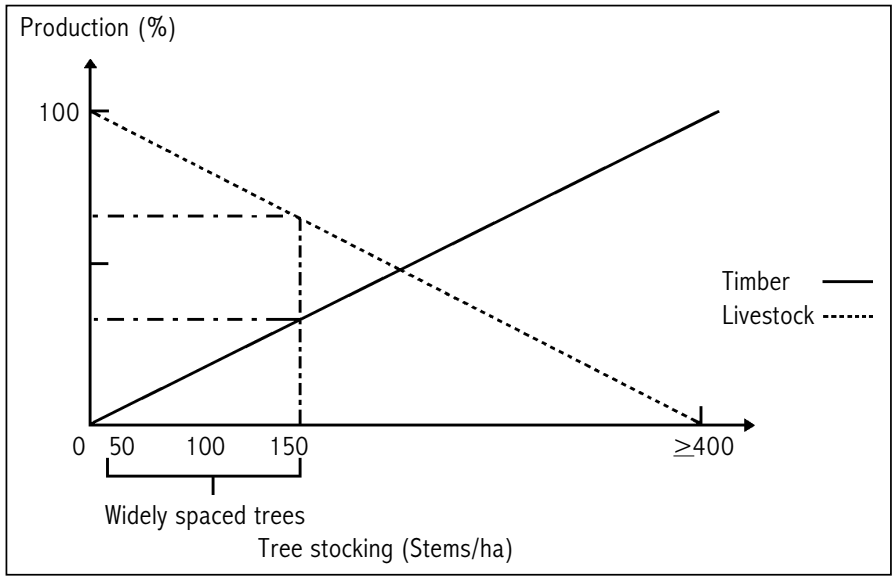

Anderson \& Moore 1987; Ong et al. 1996). Lower PAR delays the rate of pasture development, but reductions in growth are partly offset by morphological changes in the plants resulting from a reduced $R$ :FR caused by the filtering effect of tree foliage. A low R:FR ratio is an important signal used by plants to increase plant stem, internode, lamina or petiole lengths, in order to optimise PAR interception by pasture leaves (Mitchell \& Woodward 1988). Indirectly the number of grass tillers and legume runners also decrease under shade (Ludlow et al. 1974), and so understorey pasture swards are less dense than open pastures (Percival et al. 1988). The soluble-carbohydrate content in ryegrass (Lolium perenne

\section{Approach}

Because little has been published in New Zealand on spaced-planted hardwood conservation tree systems, most information obtained was from associated arable land shelter belts, Pinus radiata agroforestry, overseas silvipastoral studies, and from pasture and animal research which has relevance to tree-pasture systems. A large body of information exists as unpublished reports, technical bulletins and in the minds of practitioners. As part of the review, key researchers, soil conservators and farmers who have had a close association with hardwood conservation tree planting and management were consulted.

\section{Tree effects on the hill farm microclimate}

New Zealand research on microclimatic changes caused by trees is based mainly on Pinus radiata agroforestry and shelter belts. Changes to the radiation balance and surface wind flow are thought to be of particular importance when trees are introduced into pastoral systems, as they combine to regulate the energy balance of both understorey and overstorey. This in turn influences plant water use, temperature, and overall plant and animal productivity (Brenner 1996).

\section{Light}

New Zealand Pinus radiata tree stocking trials and overseas studies have demonstrated that the incidence of Photosynthetically Active Radiation (PAR) and the red-to-far-red ratio (R:FR) of light available to understorey pasture decreases under trees with larger, more dense canopies, and at higher tree stockings (Onyewotu et al. 1994; Eastham \& Rose 1988;
L.) roots and shoots decreases with lower light (Alberda 1965), reducing pasture regrowth and suppressing general plant growth and vigour (Eriksen \& Whitney 1981; Wong \& Wilson 1980). Thus, hard grazing (i.e., leaving low residual pasture cover) should be avoided, and the intervals between grazing should be extended in comparison to the grazing management of open pasture (Hawke \& Percival 1992; Percival et al. 1988). However, the nature and actual extent of understorey pasture responses to shading, imposed by hardwood trees with different canopy structures and leaf display, planted at low stocking densities, and managed under different silvicultural regimes has not been measured in New Zealand.

\section{Wind flow and wind speed}

Measurements of the effects of trees on wind speed and air turbulence is limited to Pinus radiata agroforestry and shelter belt studies in New Zealand. Trees act as a barrier, influencing horizontal wind speed and air turbulence, as they absorb wind momentum and force air to flow around and over them (Brenner 1996). Openstructured shelter belts with high porosity such as widely spaced leafless poplar trees give relatively small, nonturbulent reductions in wind speed in comparison to more impermeable belts (Sturrock 1972). Turbulence is the main factor that affects the distance before normal wind velocity is regained (Gregory 1995). Standing trees in agroforestry systems have been shown to significantly reduce wind speed (Anderson 1991; Bird et al. 1992; Knowles 1991). Even at tree stockings of only $17 \mathrm{stems} / \mathrm{ha}$, mature river red gums in western Victoria, Australia, reduced wind speed at $1.5 \mathrm{~m}$ above ground to $50-60 \%$ of that in adjacent open paddocks (Bird et al. 1992). 


\section{Soil water balance}

Trees planted at high stockings are able to intercept large volumes of precipitation coming into a catchment and can remove large volumes of soil water by transpiration (Maclaren 1996; Fahey \& Rowe 1992). In New Zealand, Pinus radiata within the Mangatu Forest lowered the soil water table by $2 \mathrm{~m}$ in comparison to areas where trees were felled and the land was revegetated in pasture (Treeby 1989). Australian investigations into the effectiveness of different planting strategies in reducing soil water, have shown that where trees were planted to cover $35 \%$ of lower slope and discharge zones, the water table was lowered by $2 \mathrm{~m}$ over a 9- to 10 -year period. Widely spaced plantations also lowered the water table by $1.6 \mathrm{~m}$ over 10 years (Schofield 1991). It is evident that strategic plantings of trees can be used to lower water tables where drainage (surface or subsurface) is not feasible for technical or economic reasons, and in doing so can reduce the susceptibility of wet soils to stock treading damage. However, there is very limited information available on the effects of widely spaced hardwood trees on the soil water balance (Wallace 1996).

\section{Tree effects on the soil resource}

Trees can improve the physical and chemical properties of soils by providing organic matter from either litter and/or root decay. The effect that different tree species have on the surrounding micro-environment (soil water distribution, soil temperature and soil $\mathrm{pH}$ ) and variation in the quantity and composition of tree organic matter also influences the biological properties of soils (Binkley 1995; Schroth 1995; Palm 1995). Canadian research has found that poplar stands have relatively high rates of nutrient cycling compared with most temperate forest species (Bernier 1984), and as well as supplying nitrogen via litter, root excretion and/or root decay, many tree species used for soil conservation (e.g., alders, acacias and robinias) are able to fix significant amounts of atmospheric nitrogen through symbiotic relationships (Maclaren 1996; Sheppard et al. 1984; Bulloch 1983).

Turnover of fine tree roots and associated mycorrhiza have been shown to contribute $2-4$ times more nitrogen, and 6-10 times more phosphorus, than above-ground litter fall (Bowen 1984 cited by Palm 1995). A tree's ability to extend considerable distances laterally, especially at low tree stockings, means its roots influence the soil at distances far beyond the area affected by leaf fall (Schroth 1995).

Trees are highly efficient at utilising nutrients present in forest-soil or agroforestry systems. Several New Zealand investigations under Pinus radiata have shown low leaching losses of nitrates compared with the total nitrogen content in the system (Dyck et al. 1981; Knight \& Will 1977).

\section{Tree effects on pasture production}

Changes to the microclimate, water balance and soil properties by trees in turn affect pasture production, but there have been very few studies on the effects of hardwood trees on the production of hill land pastures. Data that are available (Gilchrist et al. 1993; Miller et al. 1996) are based on point-in-time experiments of either single trees or trees at high stockings. The progressive impacts of widely spaced (25-150 stems/ ha) hardwood trees on pasture production and quality, as the trees mature and their canopies develop, are unknown. Similarly the competitive interactions that hardwood trees have with hill pastures for available soil water and nutrients have not been measured.

Miller et al. 1996 observed at high tree stockings (400 stems/ha), 6- to 10-year-old willows formed a dense canopy which reduced annual pasture yields by $40 \%$ relative to that on stable open ground, but were similar to open pasture yields on unstable earthflows, and were higher than yields on recently disturbed ground. As found with other tree species such as Pinus radiata, under densely planted willows (400 stems/ha) the ryegrass and clover component of the pasture sward is lower than that of open pasture. Gilchrist et al. (1993) found that around single hardwood soil conservation trees pasture dry matter yields were similar to those of open pasture during winter, but in spring were significantly reduced closer to the trees. Through summer and autumn, reductions in pasture yields progressively became more uniform over entire paddocks.

\section{Tree effects on animal production}

New Zealand and Australian agroforestry research has shown general declines (lower ewe liveweights, lamb growth rates and wool weights) in animal productivity under Pinus radiata compared with that from open pasture (Anderson \& Moore 1987; Bird et al. 1995; Percival et al. 1988; Knowles 1991). Animal production was lower at high tree stockings ( $>100$ stems/ha) and under mature trees with greater crown dimensions (Table 1) (Hawke \& Percival 1992). Factors attributed to the reduced animal production under Pinus radiata include: a reduction in annual pasture dry matter yields; a lower ryegrass and white clover component in the pasture sward; less dense pasture swards; an increased prevalence of gastro-intestinal parasites; and a greater proportion of low digestibility tree litter in the animal's diet (Anderson \& Moore 1987; Percival \& Hawke 1985; Percival et al. 1988; Bird et al. 1995). 
Table 1 Wool production (expressed as a percentage of production achieved on open pasture) from a Pinus radiata agroforestry site (Bird et al. 1995).

\begin{tabular}{ccc}
\hline Tree age (years) & 60 stems/ha & 200 stems/ha \\
\hline 9 & 99 & 94 \\
10 & 93 & 73 \\
11 & 89 & 68 \\
12 & 87 & 59 \\
13 & 89 & 42 \\
\hline
\end{tabular}

Widely spaced hardwood soil conservation tree plantings may affect animal production differently from Pinus radiata. This is because trees are generally planted at low overall stockings ( 25 to 150 stems/ha); trees are planted close to final stocking ratios; poplar, willow, and eucalyptus trees generally have narrower, more open, canopies; the use of individually protected poplar and willow poles allows trees to be directly planted into erosion-susceptible areas of farms without having to exclude grazing livestock; and tree foliage from poplars and willows is nutritious and reasonably palatable to browsing livestock.

On land that is highly susceptible to erosion, any suppression of pastures by widely spaced trees is often counterbalanced by the utilisation of pasture on areas that otherwise would not have been available for grazing. The stabilisation of this land allows more efficient feed utilisation (Hicks 1995). Increases of approximately seven stock units/ha in annual stock carrying capacity have been recorded on spaced-planted, previously unstable ground on the East coast and the Wairarapa (Hicks 1995).

\section{Tree effects on animal welfare}

Animal welfare issues are attaining greater importance to New Zealand's primary export industries with the realisation of the potential market consequences if our standards of practice fall below those of our trading partners (Sutton 1990). Under the Animals Protection Act 1960, a code of recommendations and minimum standards has been set for all farm animals, including, freedom from discomfort and freedom from distress (Anon. 1994). In relation to these requirements, trees provide shade and shelter for grazing animals which reduces their exposure to direct ultra-violet radiation, temperature extremes, high wind speeds and driving rains (Bird et al. 1992; Gregory 1995). As a result trees also reduce energy required by animals to maintain a constant deep body temperature (Bird et al. 1992). However, under field conditions in New Zealand's temperate environment, the theoretical advantages of shelter have been difficult to prove as results have often been inconsistent (King \& Sturrock 1984; Knowles 1991).

Trees can have positive effects on animal behaviour by reducing visual stimuli. This substantially reduces aggression in bulls and farmed red deer hinds (Chamove \& Grimmer 1993; Whittington \& Chamove 1995). Reduced stress, in a tree environment, is also attributed to increased calving percentages for sika and red deer (Crofskey 1988).

\section{Additional benefits of trees}

Certain soil conservation trees (e.g., poplars and willows) can be used as a source of fodder when there is a shortage of pasture during summer droughts (Hewson 1993; Hathaway 1986). Where carefully sited and managed, some poplar, acacia, robinia, alder, and eucalyptus species have timber values (Anon. 1995; van Kraayenoord 1987). The use of a variety of hardwood tree species also improves the amenity value of the farmers working environment and overall value of the farm (Lucas 1983).

\section{Summary}

Where hardwood soil conservation trees are adequately planted and tended they significantly reduce the magnitude of soil erosion, along with the associated detrimental impacts on pasture production and utilisation. Many of the hardwood tree species used in New Zealand for soil conservation also have positive effects on the soils of hill farms. This is owing to the addition of valuable organic matter to the soil, in some instances higher nitrogen fixation, and improved drainage of wet soils. However, even though relatively open-crowned and widely spaced hardwood trees have the potential to reduce the negative effects that Pinus radiata has on pasture and animals, as yet there is very limited numerical evidence to support such a hypothesis. Clearly, further research is required to demonstrate the value of silvipastoral systems utilising hardwood trees.

\section{REFERENCES}

Alberda,T.H. 1965. The influence of temperature, light intensity and nitrate concentration on dry-matter production and chemical composition of Lolium perenne L. Netherlands journal of agricultural science 13(4): 335-360.

Anderson, G. 1991. Benefits, limitations and management of a fully integrated agroforestry system. Agricultural science 4(4): 15-17.

Anderson, G.W.; Moore, R.W. 1987. Annual pasture productivity in the first seven years of a Pinus radiata 
agroforest in Western Australia. Australian journal of experimental agriculture 27: 231-238.

Anon. 1994. The Animals Protection Act 1960 and its implications for those responsible for farm animals. Animal Welfare Advisory Committee, Wellington, New Zealand.

Anon. 1995. Special Purpose Timber Species. pp. 2151 In Small Forest Management 1, Wellington, New Zealand, Ministry of Forestry.

Bernier, B. 1984. Nutrient cycling in Populus: A literature review with implications in intensivelymanaged plantations. IEA/ENFOR joint report, Canadian Forestry Service Department of Environment, Ottawa, Ontario, Canada.

Binkley, D. 1995. The influence of tree species on forest soils: Processes and patterns. pp. 1-33 In Proceedings of the trees and soil workshop, Lincoln University, Agronomy Society of New Zealand Special Publication No. 10, Mead, D.J.; Cornforth, I.S. (eds); Canterbury, New Zealand, Lincoln University Press.

Bird, P.R.; Bicknell, D.; Bulman, P.A.; Burke, S.J.; Leys, J.F.; Parker, J.N.; van der Sommen, F.J.; Voller, P. 1992. The role of shelter in Australia for protecting soils, plants and livestock. Agroforestry systems 20: 59-86.

Bird, P.R.; Kellas, J.D.; Kearney, G.A.; Cumming, K.N. 1995. Animal production under a series of Pinus radiata-pasture agroforestry systems in south-west Victoria, Australia. Australian journal of agricultural research 46(6): 1299-1310.

Blaschke, P.M.; Trustrum, N.A.; DeRose, R.C. 1992. Ecosystem process and sustainable land use in New Zealand steeplands. Agriculture, ecosystems and environment 41: 153-178.

Brenner, A.J. 1996. Microclimatic modifications in agroforestry. pp. 159-183 In Tree-crop Interactions - A Physiological Approach, Ong, C.K.; Huxley, P. (eds). Cambridge UK, University Press, CAB International.

Bulloch, B.T. 1983. Alders - alternative trees for soil conservation. Streamland 17. National Water and Soil Conservation Organisation.

Chamove, A.S. \& Grimmer, B. 1993. Reduced visibility lowers bull aggression. Proceedings of the New Zealand Society of Animal Production 53: 207-208.

Clough, P.; Hicks, D. 1993. Soil conservation and the resource management act. Summary. MAF Policy Technical Paper 93/2. MAF Policy, Wellington, New Zealand.

Crofskey, L. 1988. Deer in agroforestry. pp. 59-69 In Agroforestry Symposium Proceedings, Maclaren, P. (ed.); New Zealand Ministry of Forestry, Forest Research Institute, Bulletin No. 139.
DeRose, R.C.; Trustrum, N.A.; Thomson, N.A.; Roberts, A.H.C. 1995. Effect of landslide erosion on Taranaki hill pasture production and composition. New Zealand journal of agricultural research 38: 457471.

Douglas, G.B.; Trustrum, N.A.; Brown, I.C. 1986. Effect of soil slip erosion on Wairoa hill pasture production and composition. New Zealand journal of agricultural research 29: 183-192.

Dyck, W.J.; Webber, B.D.; Barton, P.G. 1981. SoilWater nutrient concentrations after clearfelling and burning of Pinus radiata. New Zealand journal of forestry science 11(2): 128-144.

Eastham, J.; Rose, C.W. 1988. Pasture evapotranspiration under varying tree planting density in an agroforestry experiment. Agricultural water management 15: 87-105.

Eriksen, F.I.; Whitney, A.S. 1981. Effects of light intensity on growth of some tropical forage species. 1. Interaction of light intensity and nitrogen fertilisation of six forage grasses. Agronomy journal 73: 427-433.

Eyles, G.O.; Newsome, P.F. 1992. A soil conservation approach to sustainable land use. pp. 216-220, The Proceedings of the International Conference on Sustainable Land Management, Napier, New Zealand, 17-23 November, 1991.

Fahey, B.D.; Rowe, L.K. 1992. Land-use impacts. pp. 265-284 In Waters of New Zealand, Mosley, M.P. (Ed); New Zealand Hydrological Society.

Gilchrist, A.N.; Dez Hall, J.R.; Foote, A.G.; Bulloch, B.T. 1993. Pasture growth around broad-leaved trees planted for grassland stability. Proceedings of the XVII International Grassland Congress: 2062-2063.

Gregory, N.G. 1995. The role of shelterbelts in protecting livestock: A review. New Zealand Journal of Agricultural Research 38: 423-450.

Hathaway, R.L. 1986. Short-rotation coppiced willows for sheep fodder in New Zealand. New Zealand Agricultural Science 20(3): 140-142.

Hawke, M.F.; Percival, N.S. 1992. Sheep growth rates under Pinus radiata. Proceedings of the New Zealand Society of Animal Production 52: 229-231.

Hewson, O. 1993. Otago Regional Council - poplars and willows. New Zealand tree grower 14(1): 2728.

Hicks, D.L. 1995. Control of soil erosion on farmland. A summary of erosion's impact on New Zealand agriculture, and farm management practices which counteract it. MAF Policy Technical Paper 95/4, MAF Policy, Wellington, New Zealand.

Hicks, D.L.; Fletcher, J.R.; Eyles, G.O.; McPhail, C.R.; Watson, M. 1993. Erosion of hill country in the Manawatu-Wanganui region 1992: Impacts and 
options for sustainable land use. Contract report LC 9394/51, Landcare Research Ltd.

King, M.; Sturrock, J.W. 1984. Shelter and the hill country environment. pp. 37-52 In Water and Soil Miscellaneous Publication No. 59: Shelter research needs in relation to primary production: The report of the National Shelter Working Party, Sturrock, J.W. (Ed); Water and Soil Division, Ministry of Works and Development, Wellington, New Zealand.

Knight, P.J.; Will, G.M. 1977. A field lysimeter to study water movement and nutrient content in a pumice soil under Pinus radiata forest II - Deep seepage and nutrient leaching in the first 12 years of tree growth. New Zealand journal offorestry science 7(3): 274-296.

Knowles, R.L. 1991. New Zealand experience with silvipastoral systems: A review. Forest ecology and management 45: 251-267.

Lambert, M.G.; Trustrum, N.A.; Costall, D.A. 1984. Effect of soil slip erosion on seasonally dry Wairarapa hill pastures. New Zealand journal of agricultural research 27: 57-64.

Lucas, D. 1983. Rural landscape development. New Zealand agricultural science 17(4): 329-332.

Ludlow, M.M.; Wilson, G.L.; Heslehurst, M.R. 1974. Studies on the productivity of tropical pasture plants. $\mathrm{V}^{*}$ Effects of shading on growth, photosynthesis and respiration in two grasses and two legumes. Australian journal of agricultural research 25: 425433.

Maclaren, J.P. 1996. Environmental effects of planted forests in New Zealand. Forest Research Institute Bulletin No. 198. New Zealand Forest Research Institute.

Maclaren, J.P. 1988. Agroforestry symposium proceedings. New Zealand Ministry of Forestry, Forest Research Institute, Bulletin No. 139.

Miller, D.E.K.; Gilchrist, A.N.; Hicks, D.L. 1996. The role of broad-leaved trees in slope stabilisation in New Zealand pastoral farming. pp. 96-104 In Mountains of East Asia and the Pacific, Ralston, M.M.; Hughey, K.F.D.; O'Connor, K.F. (eds); New Zealand: Centre for Mountain Studies, Lincoln University, Canterbury, New Zealand.

Mitchell, P.L.; Woodward, F.I. 1988. Response of three woodland herbs to reduced photosynthetically active radiation and low Red to Far Red ratio in shade. Journal of applied ecology 76: 807-825.

Ong, C.K.; Black, C.R.; Marshall, F.M.; Corlett, J.E. 1996. Principles of resource capture and utilisation of light and water. pp. 130-150 In Tree-crop Interactions - A Physiological Approach, Ong, C.K.; Huxley, P. (eds) Cambridge UK, University Press: $\mathrm{CAB}$ International.
Onyewotu, L.O.Z.; Ogigirigi, M.A.; Stigter, C.J. 1994. A study of competitive effects between a Eucalyptus camaldulensis shelterbelt and an adjacent millet (Pennisetum typhoides) crop. Agriculture, ecosystems and environment 51: 281-286.

Palm, C.A. 1995. Contribution of agroforestry trees to nutrient requirements of intercropped plants. Agroforestry systems 30: 105-124.

Percival, N.S.; Hawke, M.F. 1985. Agroforestry development and research in New Zealand. New Zealand agricultural science 19(3): 86-92.

Percival, N.S.; Hawke, M.F.; Jagusch, K.T.; Korte, C.J.; Gillingham, A.G. 1988. Review of factors affecting animal performance in pine agroforestry. pp. 165174. In Agroforestry Symposium Proceedings, Maclaren, P. (ed); New Zealand Ministry of Forestry, Forest Research Institute, Bulletin No. 139.

Schofield, N. 1991. Effects of tree plantations on groundwater. Agricultural science 4(4): 26-29.

Schroth, G. 1995. Tree root characteristics as criteria for species selection and systems design in agroforestry. Agroforestry systems 30: 125-143.

Sheppard, J.S.; Bulloch, B.T.; Hathaway, R.L.; Gilchrist, A.N.; Pollock, K.M. 1984. Streamland 31. National Water and Soil Conservation Authority.

Sturrock, J.W. 1972. Aerodynamic studies of shelterbelts in New Zealand. 2. Medium - height to tall shelterbelts in mid Canterbury. New Zealand journal of science 15(2): 113-140.

Sutton, J. 1990. Animal researchers and farmers must take heed of changing attitudes towards animal welfare and the protection of the environment. Proceedings of the New Zealand Society of Animal Production 50: 373-374.

Thompson, R.C.; Luckman, P.G. 1993. Performance of biological erosion control in New Zealand soft rock terrain. Agroforestry systems 21: 191-211.

Treeby, B. 1989. The Gisborne conference. New Zealand tree grower 10(2): 2-6.

Trustrum, N.A.; Thomas, V.J.; Lambert, M.G. 1984. Soil slip erosion as a constraint to hill country pasture production. Proceedings of the New Zealand Grassland Association 45: 66-76.

Van Kraayenoord, C.W.S.; Hathaway, R.L. (Eds). 1986. Plant materials handbook for soil conservation volume I. Principles and practices. Water and Soil Miscellaneous Publication No. 93. National Water and Soil Conservation Authority, Wellington, New Zealand.

Van Kraayenoord, C.W.S. 1987. New start for Black locust? Streamland 55, National Water and Soil Conservation Authority.

Wallace, J.S. 1996. Water balance of mixed tree-crop systems. pp. 192-96 In Tree-crop Interactions - A 
Physiological Approach, Ong, C.K.; Huxley, P. (eds). Cambridge, UK, University Press: CAB International.

Whittington, C.J.; Chamove, A.S. 1995. Effects of visual cover on farmed red deer behaviour. Applied animal behaviour science 45: 309-314.
Wilkinson, A. 1995. The poplar scene - New Zealand and overseas. New Zealand tree grower 17: 28-30. Wong, C.C.; Wilson, J.R. 1980. Effects of shading on the growth and nitrogen content of Green Panic and Siratro in pure and mixed swards defoliated at two frequencies. Australian journal of agricultural research 31: 269-285. 
